\title{
TINGKAT KEBERHASILAN SISTEM AGROFORESTRI DI DESA RUMBIO KECAMATAN KAMPAR KABUPATEN KAMPAR
}

\section{(Level Of Success In Agroforestry System In Rumbio Village Kampar Sub-District Kampar District)}

\author{
Riska Faridatul Hasanah ${ }^{1}$, Ervayenri ${ }^{2}$, Enny Insusanty ${ }^{2}$ \\ ${ }^{I}$ Fakultas Kehutanan Universitas Lancang Kuning \\ ${ }^{2}$ Staf Pengajar Fakultas KehutananUniversitas Lancang Kuning \\ Jln. Yos Sudarso Km 8 Rumbai Pekanbaru Telp (0761) 54092 \\ E-mail:kha_hasanah@yahoo.com,erva@unilak.ac.id,ennyinsusanty@unilak.ac.id
}

Diterima: 18 November 2019, Direvisi: 09 Desember 2019, Disetujui: 31 Desember 2019 DOI: https://doi.org/10.31849/forestra

\section{ABSTRACT}

This study aims to measure the success rate of the Agroforestry System in Rumbio Village. This research was conducted for 2 (two) months in April s.d. June 2019. Tools and materials used in the study were chest boards, label papers, questionnaires, interview guides, tally sheets, GPS, cameras, guards, phi bands, gauges, compasses, and plastic straps. While the objects studied were rubber plants, agarwood plants, and honey bee cultivation. Data collected in this study are primary and secondary data. Data collection methods used are (1) survey method with sampling techniques for measuring rubber and aloes plants; (2) filling out questionnaires and census interviews for honey bee cultivation. The results showed the success rate of kaet plants was around 53\% and agarwood plants were $28 \%$, this was due to several factors such as floods that occurred in 2017, lack of assistance, lack of plant maintenance, and for aloes plants there was no shade at the beginning of planting. As for the cultivation of honey bees, the results of this study indicate that the cultivation of honey bees is beneficial.

Keywords: Agroforestry, Rubber Plants, Agarwood Plants, Honey Bee Cultivation.

\section{ABSTRAK}

Penelitian ini bertujuan untuk mengukur tingkat keberhasilan Sistem Agroforestri di Desa Rumbio. Penelitian ini dilaksanakan selama 2 (dua) bulan pada bulan April s.d. Juni 2019. Alat dan Bahan yang digunakan dalam penelitian adalah papan dada, kertas label, kuisioner, panduan wawancara, tally sheet, GPS, kamera, haga, phi band, meteran, kompas, dan tali plastik. Sedangkan objek yang diteliti adalah tanaman karet, tanaman gaharu, dan budidaya lebah madu. Data yang dikumpulkan dalam penelitian ini adalah data primer dan sekunder. Metode pengumpulan data yang dilakukan yaitu (1) metode survei dengan teknik sampling untuk pengukuran tanaman karet dan tanaman gaharu; (2) pengisian kuisioner dan wawancara secara sensus untuk budidaya lebah madu. Hasil penelitian menunjukkan tingkat keberhasilan tanaman kaet sekitar $53 \%$ dan tanaman gaharu 28 $\%$, hal ini dikarenakan beberapa faktor seperti banjir yang terjadi pada Tahun 2017, kurangnya pendampingan, kurangnya pemeliharaan tanaman, dan untuk tanaman gaharu tidak adanya naungan pada awal penanaman. Sedangkan untuk budidaya lebah madu hasil penelitian menunjukkan bahwa budidaya lebah madu ini menguntungkan.

Keywords: Agroforestri, Tanaman Karet, Tanaman Gaharu, Budidaya Lebah Madu. 


\section{PENDAhULUAN}

Hutan sangat penting bagi kehidupan di muka bumi, terutama bagi kehidupan generasi mendatang. Pelibatan sumber daya manusia dalam pengelolaan hutan menuju hutan lestari merupakan suatu proses untuk mengikutsertakan masyarakat dalam suatu kelompok tertentu dalam pembuatan keputusan atau pemecahan masalah. Pembangunan Kebun Bibit Rakyat (KBR) merupakan salah satu program prioritas Kementerian Lingkungan Hidup dan Kehutanan yang telah dilaksanakan sejak tahun 2010. Bibit hasil KBR digunakan untuk merehabilitasi di lahan kritis, lahan kosong dan lahan tidak produktif di wilayahnya (Amir, 2011).

Selaras dengan pemerintah pusat, saat ini pemerintah Provinsi Riau maupun pemerintah daerah Kabupaten Kampar juga telah melaksanakan program kebun bibit rakyat (KBR) guna mengurangi laju lahan kritis di sekitar daerah aliran sungai. Salah satu Desa yang menerima bantuan KBR adalah Desa Rumbio yang terletak di Kabupaten Kampar Provinsi Riau dengan luas \pm 50 Ha. Sehubungan dengan pelaksanaan program yang berbasis swakelola kelompok masyarakat, dimana kelompok masyarakat merupakan penggerak sekaligus pelaksana utama program, sehingga aspek persepsi dan partisipasi masyarakat menjadi hal yang perlu untuk diketahui dalam pelaksanaan program KBR di Desa Rumbio.

Dalam pelaksanaannya, Kelompok KBR Desa Rumbio dikelola oleh Kelompok tani yang menggunakan sistem Agroforestri. Agroforestri dalam Bahasa Indonesia, dikenal dengan istilah wanatani atau agroforestri, arti sederhananya adalah menanam pepohonan di lahan pertanian/ perkebunan. Pemanfaatan lahan dengan sistem agroforestri sangat menguntungkan bagi petani karena terdiri dari tanaman semusim dan tahunan yang hasilnya lebih produktif (Hairiah K, Agung M, 2003). Pencampuran antara tanaman karet dengan Aquilaria malaccensis atau sering disebut dengan tanaman gaharu merupakan sistem agroforestri yang dilakukan oleh Kelompok Tani di Desa Rumbio. Selain pemanfaatan tanaman gaharu dan tanaman karet, petani KBR di Desa Rumbio juga memanfaatkan Hasil Hutan Non Kayu berupa Budidaya lebah madu yang sudah memiliki nilai jual. Dimana budidaya lebah madu ini akan 
mendukung pengelolaan agroforestri yang ada di Desa tersebut.

Luas lahan agroforestri yang dimiliki petani KBR di Desa Rumbio mencapai 50 ha. Lahan agroforestri yang diusahakan oleh petani merupakan lahan milik sendiri. Desa Rumbio sejak tahun 2015 dicanangkan menjadi lokasi agroforestri. Kegiatan tersebut mengkombinasikan antara tanaman kehutanan dengan perkebunan, dan peternakan dalan satu bidang lahan. Pengelolaan agroforestri tersebut dilakukan dengan memberdayakan petani khususnya petani yang tergabung dalam kelompok tani Alam Kuyang Lestari. Kegiatan pengelolaan agroforestri tersebut telah berjalan tahun keempat di tahun 2019. Dengan adanya sistem Agroforestri yang dikembangkan di Desa Rumbio tersebut, diharapkan petani KBR dapat merasakan manfaat langsung maupun tidak langsung dari keberhasilan sistem agroforestri yang dilakukan. Berdasarkan uraian diatas, peneliti melakukan penelitian yang berjudul Tingkat Keberhasilan Sistem Agroforestri di Desa Rumbio, Kecamatan Kampar, Kabupaten Kampar.
Penelitian ini bertujuan untuk mendeskripsikan proses pembangunan sistem agroforestry, mengukur tingkat keberhasilan pertumbuhan tanaman karet dan tanaman gaharu dan menghitung nilai ekonomi budidaya lebah madu di Desa Rumbio.

\section{METODE PENELITIAN}

\section{Tempat, Waktu, Alat dan Bahan}

Penelitian ini dilaksanakan di Desa Rumbio yang terletak di Kabupaten Kampar. Dilaksanakan selama 2 bulan, yaitu pada bulan April sampai bulan Juni 2019. Peralatan yang digunakan yaitu: Alat tulis, papan dada, kertas label, Kuisioner, panduan wawancara, tally sheet, Peta, GPS, Kamera, Haga, Phi band, Meteran, Kompas, Tali Plastik.

\section{Metode Pengumpulan Data}

Untuk memecahkan suatu permasalahan dalam penelitian, metode survei yang dilakukan untuk mengetahui keberhasilan pertumbuhan tanaman karet dan tanaman gaharu dilakukan dengan mendapatkan data yang valid dengan memberikan batas yang jelas kepada objek penelitian. Sedangkan untuk mengetahui nilai ekonomi budidaya lebah madu metode pengumpulan data 
dilakukan secara sensus hanya kepada anggota kelompok tani yang melakukan budidaya lebah madu dan untuk pekerjaan silvikultur tanaman karet dan gaharu dilakukan secara sensus kepada seluruh anggota kelompok tani yang berjumlah 20 orang.

\section{Teknik Pengumpulan Data}

Pengambilan data pertumbuhan tanaman karet dan tanaman gaharu dalam pelaksanaan penelitian ini di lakukan dengan menggunakan teknik sampling. Dimana pola pengamatan yang dilakukan menggunakan metode petak ukur berbentuk persegi dengan ukuran $20 \mathrm{~m}$ x 20 m pada masing - masing titik pengamatan. Dalam penempatan plot petak ukur dilakukan secara sistematis (systematic sampling) dengan menggunakan intensitas sampling yang digunakan $2 \%$, dikarenakan jenis tanaman pada areal tersebut seragam sehingga IS $2 \%$ sudah mewakili untuk pengambilan sample pengukuran. Menurut Hasanu (2017), yang dimaksud dengan intensitas sampling adalah suatu bilangan yang menggambarkan perbandingan antara jumlah sampel dengan jumlah populasi seluruhnya. Intensitas sampling dapat dinyatakan dalam bilangan desimal atau persen. Luas areal yang dimiliki kelompok tani KBR yaitu 50 Ha. Berikut cara perhitungan jumlah petak ukur yakni :

P. $\mathrm{U}=$ Luas Total $\mathrm{x}$ Intensitas Sampling (IS)

$=50 \mathrm{Ha} \times 2 \%=1 \mathrm{Ha}$

$=10.000 \mathrm{~m} 2$

Dalam menentukan jumlah petak ukur dalam penelitian ini digunakan petak ukur berukuran $20 \mathrm{~m}$ x $20 \mathrm{~m}$.

Jumlah petak ukur yang akan di hitung adalah:

$$
\text { P. } \begin{aligned}
\mathrm{U} & =\frac{10.000 \mathrm{~m}^{2}}{400 \mathrm{~m}^{2}} \\
& =25 \text { Petak Ukur }
\end{aligned}
$$

Lokasi penelitian yang akan diukur merupakan areal perkebunan kelompok tani yang berjumlah 20 orang dimana areal perkebunan tersebut tidak di satu hamparan lahan, tetapi terpisah - pisah. Melihat kondisi lapangan yang terpisah tersebut.

Pengumpulan data untuk analisis ekonomi budidaya lebah madu dan pekerjaan silvikultur tanaman dilakukan dengan pengisian kuisioner. Sampel yang digunakan dalam perhitungan nilai ekonomi budidaya lebah madu hanya kepada anggota kelompok tani yang melakukan budidaya lebah madu yaitu sebanyak 7 dari 20 orang total anggota kelompok tani yang ada. 
Sedangkan untuk pekerjaan silvikultur sampel yang digunakan yaitu sensus kepada seluruh anggota kelompok tani sebanyak 20 orang dengan total luasan lahan 50 hektar dengan luasan bervariasi untuk setiap orang anggota kelompok.

\section{Teknik Pengolahan dan Analisis Data}

Penelitian ini akan melihat bagaimana pertumbuhan Tanaman gaharu dan tanaman karet dengan melakukan perhitungan rata rata diameter dan tinggi pohon. Adapun perhitungan rata-rata diameter dilakukan dengan cara sebagai berikut:

Keterangan:

$$
D=\Sigma d / N
$$

$$
\begin{aligned}
& \mathrm{D}=\text { Rata-rata diameter }(\mathrm{cm}) \\
& \Sigma \mathrm{d}=\text { Jumlah diameter pohon }(\mathrm{cm}) \\
& \mathrm{n}=\text { Jumlah Pohon }
\end{aligned}
$$

Perhitungan rata-rata tinggi dilakukan dengan cara sebagai berikut:

$$
T=\Sigma T / N
$$

Keterangan:

$$
\begin{aligned}
& \mathrm{T}=\text { Rata-rata tinggi }(\mathrm{cm}) \\
& \Sigma \mathrm{T}=\text { Jumlah tinggi pohon }(\mathrm{cm}) \\
& \mathrm{n} \quad=\text { Jumlah Pohon }
\end{aligned}
$$

Sedangkan perhitungan rata-rata tajuk dilakukan dengan cara sebagai berikut:

$$
L t=\Sigma L t / N
$$

Keterangan:

$$
\begin{aligned}
& \mathrm{Lt}=\text { Rata-rata lebar tajuk }(\mathrm{cm}) \\
& \Sigma \mathrm{Lt}=\text { Jumlah lebar tajuk }(\mathrm{cm}) \\
& \mathrm{n} \quad=\text { Jumlah Pohon }
\end{aligned}
$$

Adapun perhitungan jumlah pohon per Ha menggunakan rumus sebagai berikut:

$$
\text { Jumlah pohon } / \mathrm{Ha}=\frac{\Sigma N(\text { pohon })}{H a(\text { Luas Lahan })}
$$

Disamping perhitungan pertumbuhan tanaman, untuk budidaya lebah madu akan di hitung nilai ekonominya dikarenakan budidaya lebah madu ini telah menghasilkan produksi. Nilai ekonomi budidaya lebah madu dapat dihitung dengan menggunakan rumus:

$$
\boldsymbol{R}=\mathbf{Q} \times \mathbf{P}
$$

Keterangan:

$$
\begin{aligned}
& \mathrm{R}=\text { Penerimaan } \\
& \mathrm{Q}=\text { Produksi Lebah }(\mathrm{kg}) \\
& \mathrm{P}=\text { Harga Madu }(\mathrm{Rp})
\end{aligned}
$$

Untuk menghitung total biaya dalam budidaya lebah madu, Soekartawi (2002) menyatakan bahwa biaya merupakan penjumlahan antara biaya tetap dan biaya variabel yang dikeluarkan selama satu tahun.

$$
T C=\mathrm{FC}+\mathrm{VC}
$$

Keterangan:

$$
\begin{aligned}
& \text { TC }=\text { Total Cost }(\text { Total biaya }) \\
& \text { FC }=\text { Fixed Cost }(\text { biayaTetap }) \\
& \text { VC }=\text { Variable Cost }(\text { biaya variabel })
\end{aligned}
$$

Untuk mengetahui keuntungan, (Soekartawi, 2006) mengatakan bahwa keuntungan usahatani adalah selisih antara penerimaan dengan biaya eksplisit dan 
implisit maka dapat dirumuskan sebagai berikut:

$$
\Pi=\mathbf{T R}-\mathbf{T C}
$$

Keterangan:

$$
\begin{aligned}
& \Pi=\text { keuntungan } \\
& \mathrm{TR}=\text { total penerimaan } \\
& \mathrm{TC}=\text { total biaya }
\end{aligned}
$$

Perhitungan analisi kelayakan Budidaya Lebah Madu dapat dihitung dengan menggunakan rumus Analisis Break Even Point yaitu:

$$
N_{B E P}=\frac{Q J}{(R-C)} x F
$$

Keterangan:

NBEP = Tingkat produksi madu pada titik impas (kg/tahun)

$\mathrm{Qj}=$ Total produksi madu setahun ( $\mathrm{kg} / \mathrm{tahun})$

$\mathrm{R}=$ Penerimaan total dari penjualan madu setahun ( $\mathrm{Rp} /$ tahun)

$\mathrm{C}=$ Biaya variabel total dari penjualan madu setahun (Rp/tahun)

$\mathrm{F}=$ Biaya tetap total dari penjualan madu setahun (Rp/tahun)

Jika jumlah penerimaan yang diperoleh ada di atas titik impas maka usaha menguntungkan dan sebaliknya jika jumlah penerimaan ada di bawah titik impas maka usaha tersebut rugi. Usaha ada dalam keadaan titik impas jika jumlah penerimaan sama dengan jumlah pengeluaran (Riyanto, 2008).

Menguntungkan atau tidaknya usahatani yang dilakukan secara ekonomi dapat dianalisi dengan menggunakan perbandingan antara penerimaan dengan biaya (Revenue Cost Ratio RCR). Secara matematis RCR dapat dirumuskan sebagai berikut (Soekartawi, 1995) :

$$
R C R=\mathrm{PT} / \mathrm{BT}
$$

Keterangan:

$$
\begin{aligned}
& \mathrm{RCR}=\text { Nisbah Penerimaan dan Biaya } \\
& \mathrm{PT}=\text { Penerimaan Total }(\mathrm{Rp}) \\
& \mathrm{BT}=\text { Biaya Total }(\mathrm{Rp})
\end{aligned}
$$

Terdapat tiga kemungkinan hasil yang diperoleh dengan perhitungan di atas, yaitu: a.) Jika $\mathrm{R} / \mathrm{C}>1$, maka usahatani yang dilakukan menguntungkan karena penerimaan lebih besar dari biaya total. b.)Jika $\mathrm{R} / \mathrm{C}=1$, maka usahatani yang dilakukan berada pada titik impas, yaitu besarnya penerimaan sama dengan biaya yang dikeluarkan. c.) Jika $\mathrm{R} / \mathrm{C}<1$, maka usahatani yang dilakukan tidak menguntungkan, karena penerimaan lebih kecil dari biaya yang dikeluarkan (Soekartawi, 1995).

Data lainnya yang di kumpulkan dalam penelitian ini akan dianalisis secara deskriptif kualitatif. Data lain tersebut diantaranya adalah data tindakan silvikultur anggota kelompok tani yang dihimpun dari hasil wawancara, pengisian kuisioner dan observasi. 
III. HASIL DAN PEMBAHASAN

\section{a. Pembangunan Sistem Agroforestri}

Kelompok Tani Halaman Kuyang Lestari mulai dibentuk pertama kali pada tahun 2013. Kelompok ini mulai dibentuk dari sekumpulan masyarakat yang peduli dengan hutan adat rumbio. Dari sekumpulan masyarakat tersebut dibentuklah SPKP (Sentra Penyuluh Kehutanan Pedesaan). SPKP inilah yang menajdi pemicu dalam pembentukan Kelompok Tani Hutan yang diberi nama Halaman Kuyang Lestari. Adapun tujuan pembentukan kelompok tani hutan ini sebagai wadah untuk menyatukan masyarakat- masyarakat yang peduli dengan hutan adat rumbio tersebut.

Pada tahun 2015, Kelompok Tani Halaman Kuyang Lestari ini mendapatkan bantuan bibit dalam bentuk Kerjasama Kebun Bibit Rakyat (KBR) dari Instansi Lingkungan Hidup dan Kehutanan. Berdasarkan Peraturan Menteri Kehutanan Republik Indonesia Nomor P.17/MenhutII/2012 tentang Pedoman Teknis, Kelompok Tani Halaman Kuyang Lestari memenuhi kriteria pengajuan usulan proposal Kebun Bibit Rakyat (KBR), baik dari segi persyaratan calon kelompok masyarakat KBR yang minimal jumlah anggota 15 (lima belas) orang dan terdapat areal hutan/ lahan seluas $25-100 \mathrm{Ha}$, maupun dari segi kriteria desa calon lokasi KBR yaitu berada pada sasaran areal Rehabilitasi Hutan dan Lahan (RHL) dan memiliki 1 (kelompok) yang telah ditetapkan.

Kelompok Tani Halaman Kuyang Lestari berjumlah 20 orang dengan total luas lahan yang dimiliki $50 \mathrm{Ha}$. Adapun bibit bantuan yang diterima oleh kelompok tani halaman kuyang lestari yaitu berupa dana sejumlah 50 juta. Dana yang diterima tersebut dikelola oleh kelompok tani Halaman Kuyang Lestari dengan membuat pembibitan. Dikarenakan mayoritas masyarakat desa rumbio berkebun karet, maka dibuatlah benih vegetatif karet yang ditanam ke dalam media semai di dalam polybag/kantong/wadah lainnya. Saat ini banyak masyarakat yang menerapkan sistem agroforestri, maka Kelompok Tani Halaman Kuyang Lestari melakukan pencampuran tanaman perkebunan yaitu tanaman karet dengan budidaya gaharu. Untuk tanaman gaharu dibuatlah pembibitan gaharu dimana bibitnya berasal 


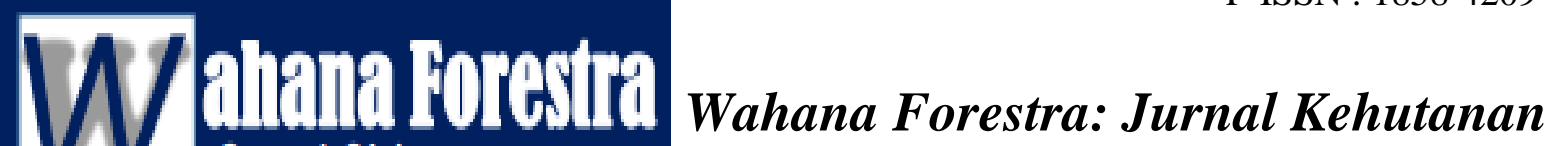 gutnal Kehutanan}

dari bibit cabutan yang ditanam di dalam polibag.

Pola tanam gaharu dengan sistem agroforestry sudah mulai banyak dilakukan pada beberapa daerah lain seperti pencampuran antara tanaman karet dengan Aquilaria malaccensis terdapat di Kabupaten Banyuasin - Sumatera Selatan, Kabupaten Merangin, Jambi (Sulistiono, Insusanty, \& Azwin, 2018). Adapun jumlah
Halaman Kuyang Lestari yaitu bibit tanaman gaharu sebanyak 10.000 batang dan bibit tanaman karet sebanyak 15.000 batang. Bibit - bibit ini ditanam di areal lahan milik kelompok tani halam kuyang lestari yang anggotanya berjumlah 20 orang dengan total luas lahan yang mereka miliki $50 \mathrm{Ha}$. Berikut tabel 1 Identitas anggota Kelompok Tani Halaman Kuyang Lestari yang berada di Desa Rumbio:

t Tabel 1. Identitas Anggota Kelompok Tani Halaman Kuyang Lestari

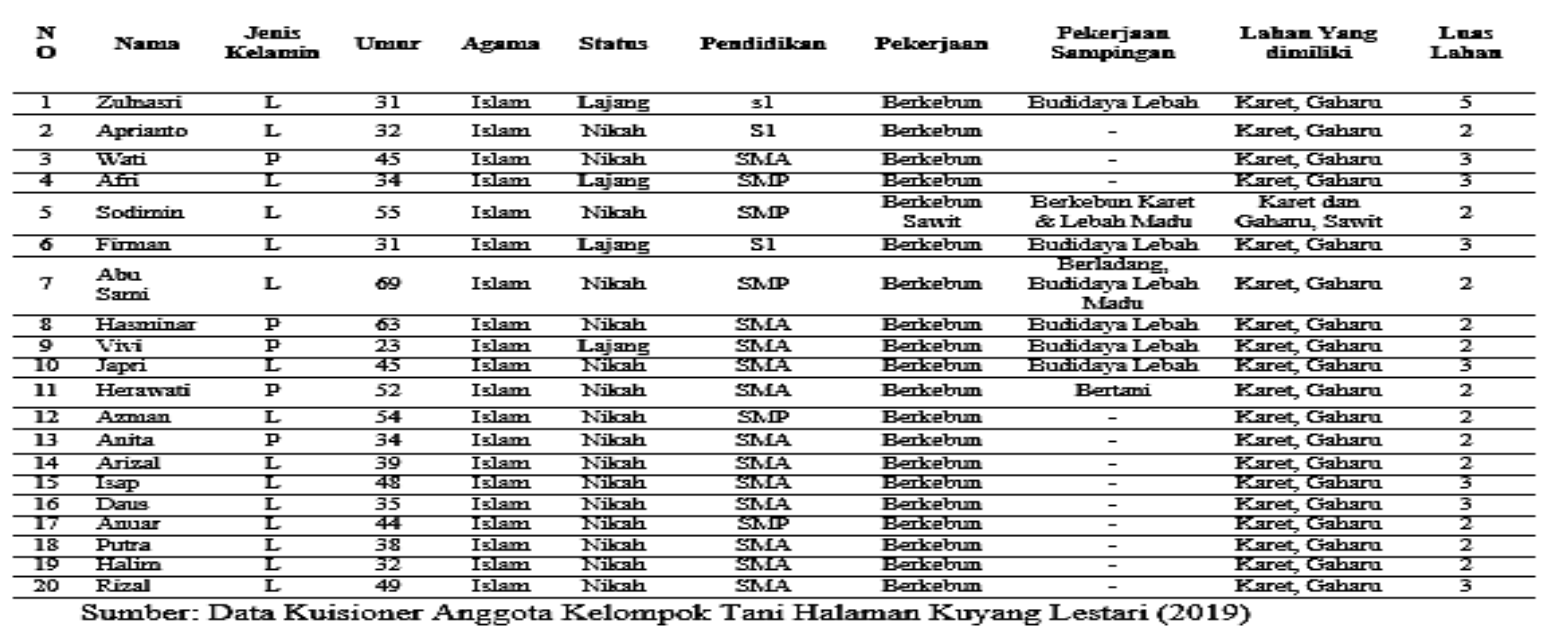

\section{b. Tingkat Keberhasilan Karet}

Tanaman karet pada areal Kelompok Tani Halaman Kuyang Lestari ditanam pada tahun 2015 sebanyak 15.000 batang. Tanaman tersebut disebar rata ke seluruh areal lahan $50 \mathrm{Ha}$ yang dimiliki oleh Kelompok Tani Halaman Kuyang Lestari. Berikut tabel 2 rata - rata pertumbuhan tanaman karet pada areal Kelompok Tani Halaman Kuyang Lestari:

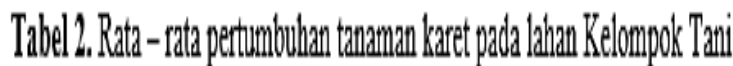
Halaman Kulyang Lestai

$$
\text { DLAMETER TINGG }
$$

\begin{tabular}{|c|c|c|c|}
\hline Total Diameter (DD) & 17.980 & Total Tingel $(5 \mathrm{t})$ & 3.5664 \\
\hline Total Pohoul $(2 \mathrm{u})$ & 618 & Total Ponot $(\sqrt{1})$ & 618 \\
\hline Rata - rath diameder & 20,09 & Rath - atatingen & $37 \%$ \\
\hline
\end{tabular}


Dari tabel 2 dapat diketahui bahwa rata - rata diameter tanaman karet hingga saat ini 29,09 $\mathrm{cm}$ dengan total sample pohon karet yang diukur yaitu 618 pohon. Sedangkan tinggi rata -rata tanaman karet yaitu $5,75 \mathrm{~m}$ dengan total pohon yang diukur 618 pohon. Adapun rata - rata hasil pengukuran tanaman karet per PU pada areal lahan kelompok tani halaman kuyang lestari sebagai

berikut:

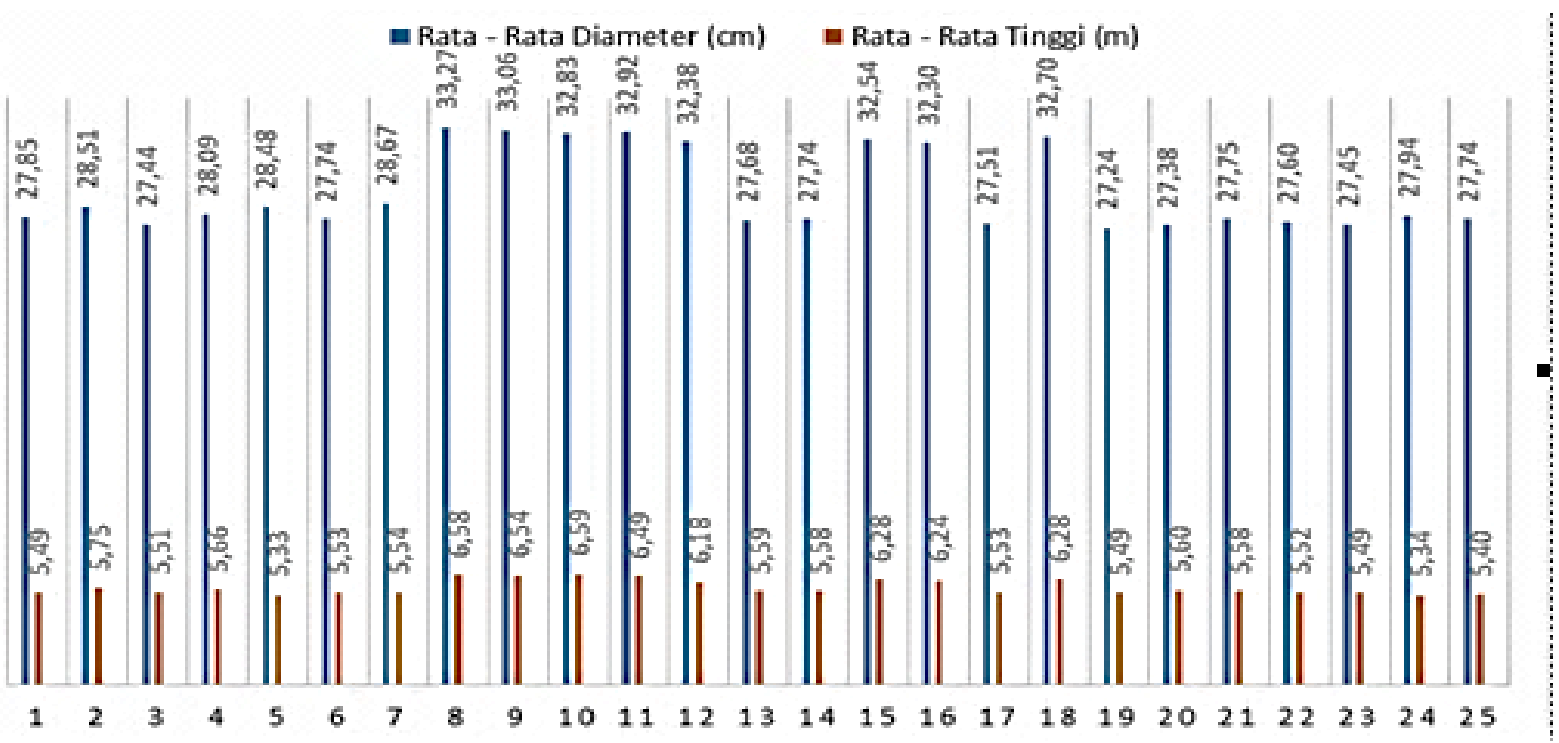

Gambar 1. Rata-Rata Hasil Pengkuran Tanaman Karet per PU Pada Areal Lahan Kelompok Tani Halaman Kuyang Lestari

Dari grafik gambar 1, diketahui bahwa pertumbuhan diameter karet tertinggi terdapat pada PU 8 yaitu dengan diameter rata - rata $33.27 \mathrm{~cm}$ dengan tinggi rata rata 6.58 meter, selanjutnya PU 9 dengan diameter rata - rata $33.06 \mathrm{~cm}$ dan memiliki tinggi rata - rata 6.54 meter. Sedangkan diameter terendah terdapat pada PU 19 dengan diameter rata - rata yang dimiliki $27.24 \mathrm{~cm}$ dan rata - rata tinggi 5.49 meter.

Keberhasilan tanaman karet pada Kelompok Tani Halaman Kuyang Lestari dapat diketahui melalui jumlah tanaman yang hidup. Jumlah bibit yang ditanam pada lahan Kelompok Tani Halaman Kuyang Lestari seluas 50 Ha pada tahun 2015 yaitu 15.000 batang. Adapun jumlah tanaman karet yang berhasil tumbuh sebagai berikut: 


\begin{tabular}{|c|c|c|c|c|c|}
\hline No & Nama & $\begin{array}{c}\text { Luas } \\
\text { Lahain } \\
\text { (Ha) }\end{array}$ & $\begin{array}{l}\text { Jumalah } \\
\text { Bibit } \\
\text { ditanam } \\
\text { (btg) }\end{array}$ & $\begin{array}{l}\text { Tanaman } \\
\text { Hidup saat } \\
\text { ini (btg) }\end{array}$ & \multirow{2}{*}{$\begin{array}{c}\text { Persentase } \\
\text { keberhasilan tanaman } \\
\text { karet yang hidup } \\
52,3 \%\end{array}$} \\
\hline 1 & Zu1nasii & 5 & 1500 & 785 & \\
\hline 2 & Aprianto & 2 & 600 & 265 & $44,2 \%$ \\
\hline 3 & Wati & 3 & 900 & 378 & $42,0 \%$ \\
\hline 4 & Afri & 3 & 900 & 426 & $47,3 \%$ \\
\hline 8 & Hasminar & 2 & 600 & 380 & $63,3 \%$ \\
\hline 9 & Vivi & 2 & 600 & 387 & $64,5 \%$ \\
\hline 10 & Japri & 3 & 900 & 445 & $49,4 \%$ \\
\hline 111 & Herawati & 2 & 600 & 412 & $68,7 \%$ \\
\hline 12 & Azman & 2 & 600 & 385 & $64,2 \%$ \\
\hline 13 & Anita & 2 & 600 & 310 & $51,7 \%$ \\
\hline 14 & Arizal & 2 & 600 & 400 & $66,7 \%$ \\
\hline 20 & Rizal & 3 & 900 & 370 & $41,1 \%$ \\
\hline & Jumla & & 15.000 & 7.901 & $53 \%$ \\
\hline
\end{tabular}

Sumber: Hasil Kuisioner Penelitian (2019)

Dari tabel 3 dapat diketahui bahwa persentase tanaman karet yang hidup hanya $53 \%$. Berdasarkan wawancara dengan kelompok tani halaman kuyang lestari diketahui bahwa tingkat keberhasilan tanaman tertinggi yaitu pada lahan Herawati dengan persentase tanaman yang hidup 68,7 \%, dan Firman dengan persentase tanaman yang hidup $65 \%$. Sedangkan persentase persentase tanaman yang hidup yang paling rendah yaitu pada lahan milik Halim dengan persentase tanaman yang hidup $41 \%$.

Dilihat dari proses perlakuan silvikultur yang dilakukan oleh anggota Kelompok Tani Halaman Kuyang Lestari diketahui bahwa anggota kelompok tani yang memiliki persentase yang tinggi diantaranya Herawati (69 \%), Arizal (67
$\%)$, Firman (65 \%) dan Vivi (65\%) ini melakukan pemeliharaan pada tahun pertama terhadap tanaman tanaman yang ditanam diantaranya pemberian pupuk NPK dan urea, penyulaman yang dilakukan terhadap tanaman yang rusak dan penyiangan sebanyak 2 (dua) kali dalam satu tahun. Selain memiliki persentase yang tinggi, tanaman yang diberi perlakuan silvikultur juga memiliki tinggi dan diameter yang tinggi dibandingkan dengan yang tidak diberi pemeliharaan. Sedangkan anggota kelompok tani yang tidak melakukan pemeliharaan memiliki persentasi tanaman hidup yang rendah diantaranya Halim (41\%), Rizal (41\%), Wati (42\%), Isap (44\%) dan Apriyanto (44\%). 
Beberapa faktor lain yang

lahan Kelompok Tani Halaman Kuyang mempengaruhi rendahnya persentase Lestari:

keberhasilan tanaman karet pada Kelompok Tani Halaman Kuyang Lestari diantaranya yaitu banjir yang terjadi pada Tahun 2017 sehingga menyebabkan banyak tanaman karet yang mati terkena banjir, selain itu hama babi, monyet juga menjadi kendala dalam pertumbuhan tanaman karet di lahan Kelompok Tani Halam Kuyang Lestari ini.

\section{c. Tingkat Keberhasilan Gaharu}

Tanaman gaharu pada areal Kelompok Tani Halaman Kuyang Lestari ditanam pada tahun 2015 sebanyak 10.000 batang. Tanaman tersebut ditanam di seluruh areal lahan $50 \mathrm{Ha}$ yang dimiliki oleh Kelompok Tani Halaman Kuyang Lestari. Berikut ratarata pertumbuhan tanaman gaharu pada

Tabel 4. Rata - rata pertumbuhan tanaman gaharu pada lahan Kelompok Tani Halaman Kuyang Lestari

\begin{tabular}{|c|c|c|c|}
\hline \multicolumn{2}{|c|}{ DIAVIETER(cm) } & \multicolumn{2}{|c|}{$\begin{array}{l}\text { TINGGI BEBAS CABANG (Tbc) } \\
(\mathrm{m})\end{array}$} \\
\hline 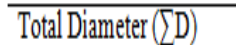 & 5.748 & Total Tinggi $(\sqrt{t})$ & 856,0 \\
\hline Total Pohon ( $(\mathrm{n})$ & 353 & Total Pohon $(\overline{2 n})$ & 353 \\
\hline Rata - rata diameter $(\mathrm{cm})$ & 16,28 & Rata - rata Tbc (m) & 2,42 \\
\hline
\end{tabular}

Dari tabel 4 dapat diketahui bahwa rata - rata diameter tanaman gaharu hingga tahun 2019 yaitu $16,28 \mathrm{~cm}$ dengan total sampel pohon gaharu yang diukur yaitu 353 pohon. Sedangkan tinggi bebas cabang rata -rata tanaman gaharu yaitu 2,42 m dengan total pohon yang diukur 353 pohon. Adapun rata - rata hasil pengukuran tanaman gaharu per Petak Ukur (PU) pada areal lahan Kelompok Tani Halaman Kuyang Lestari sebagai berikut:

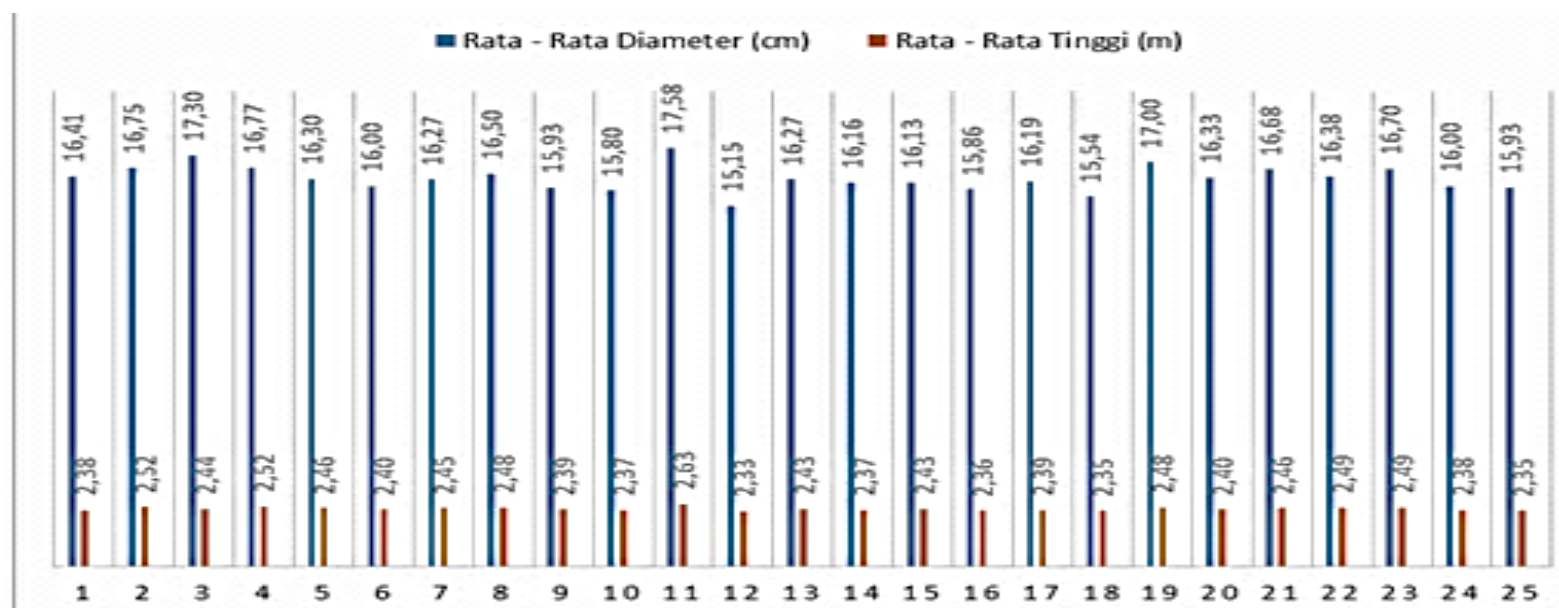

Gambar 1. Rata-Rata Hasil Pengkuran Tanaman Gaharu per PU Pada Areal Lahan Kelompok Tani Halaman Kuyang Lestari 
Dari grafik gambar 2 dapat diketahui bahwa pertumbuhan diameter tanaman gaharu tertinggi terdapat pada PU 11 yaitu dengan diameter rata - rata 17,58 $\mathrm{cm}$ dengan tinggi bebas cabang rata - rata 2,63 meter, dan PU 3 dengan diameter rata - rata 17,30 cm yang memiliki tinggi bebas cabang rata - rata 2,44 meter. Sedangkan diameter terendah terdapat pada PU 12 dengan diameter rata - rata yang dimiliki $15,15 \mathrm{~cm}$ dan rata - rata tinggi bebas cabang 2,33 meter.

Keberhasilan tanaman gaharu pada Kelompok Tani Halaman Kuyang Lestari dapat diketahui melalui jumlah tanaman yang hidup. Jumlah bibit gaharu yang ditanam pada lahan Kelompok Tani
Halaman Kuyang Lestari seluas 50 Ha pada tahun 2015 yaitu 10.000 batang. Gaharu termasuk jenis tanaman yang semitoleran, Muin (2018) mengatakan bahwa untuk jenis-jenis semitoleran, naungan untuk anakan diperlukan sampai umur 3-4 tahun atau sampai tanaman mencapai tinggi 1-3 meter. Tanaman gaharu pada lahan Kelompok Tani Halaman Kuyang Lestari ditanam pada tahun yang bersamaan dengan tanaman karet yaitu pada tahun 2015, sehingga dengan kondisi tersebut tanaman gaharu tidak mendapatkan naungan dan memiliki persentase pertumbuhan yang rendah yaitu $\pm 28 \%$. Adapun jumlah tanaman gaharu yang berhasil tumbuh terdapat pada sebagai berikut:

Tabel 5. Persentase keberhasilan tanaman gaharu pada areal Kelompok Tani Halaman Kuyang Lestari

\begin{tabular}{|c|c|c|c|c|c|}
\hline No & Nama & $\begin{array}{c}\text { Luas } \\
\text { Lahan } \\
\text { (Ha) }\end{array}$ & $\begin{array}{l}\text { Jumlah } \\
\text { Bibit } \\
\text { ditanam } \\
\text { (btg) }\end{array}$ & $\begin{array}{l}\text { Tanaman } \\
\text { Hidup saat } \\
\text { ini btg }\end{array}$ & $\begin{array}{c}\text { Persentase } \\
\text { keberhasilan tanaman } \\
\text { karet yang hidup }\end{array}$ \\
\hline 1 & Zulnasri & 5 & 1000 & 325 & $32,5 \%$ \\
\hline 2 & Aprianto & 2 & 400 & \pm 95 & $23,8 \%$ \\
\hline 3 & Wati & 3 & 600 & 120 & $20,0 \%$ \\
\hline 4 & Afri & 3 & 600 & 155 & $25,8 \%$ \\
\hline 5 & Sodimin & 2 & 400 & 140 & $35,0 \%$ \\
\hline 6 & Firman & 3 & 600 & 186 & $31,0 \%$ \\
\hline 7 & Abu Sami & 2 & 400 & 84 & $21,0 \%$ \\
\hline 8 & Hasminar & 2 & 400 & 153 & $38,3 \%$ \\
\hline 9 & Vivi & 2 & 400 & 87 & $21,8 \%$ \\
\hline 10 & Japri & 3 & 600 & 226 & $37,7 \%$ \\
\hline 11 & Herawati & 2 & 400 & 146 & $36,5 \%$ \\
\hline 12 & Azman & 2 & 400 & 130 & $32,5 \%$ \\
\hline 13 & Anita & 2 & 400 & 125 & $31,3 \%$ \\
\hline 14 & Arizal & 2 & 400 & so & $20,0 \%$ \\
\hline 15 & Isap & 3 & 600 & 150 & $25,0 \%$ \\
\hline 16 & Daus & 3 & 600 & 170 & $28,3 \%$ \\
\hline 17 & Anuar & 2 & 400 & 135 & $33,8 \%$ \\
\hline 18 & Putra & 2 & 400 & 130 & $32,5 \%$ \\
\hline 19 & Halim & 2 & 400 & 85 & $21,3 \%$ \\
\hline 20 & Rizal & 3 & 600 & 120 & $20,0 \%$ \\
\hline \multicolumn{3}{|c|}{ Jumlah } & 10.000 & 2.842 & $28 \%$ \\
\hline
\end{tabular}


Dari tabel 5 dapat diketahui bahwa persentase tanaman gaharu yang hidup hanya $28 \%$. Berdasarkan wawancara dengan kelompok tani halaman kuyang lestari diketahui bahwa tingkat keberhasilan tanaman tertinggi yaitu pada lahan Hasminar dengan persentase tanaman yang hidup $38,3 \%$, dan Japri dengan persentase tanaman yang hidup $37,7 \%$. Sedangkan persentase persentase tanaman yang hidup yang paling rendah yaitu pada lahan milik Wati, Arizal dan Rizal dengan persentase tanaman yang hidup $20 \%$.

Dilihat dari proses perlakuan silvikultur terhadap tanaman gaharu yang dilakukan oleh anggota kelompok tani Halaman Kuyang Lestari diketahui bahwa anggota kelompok tani yang memiliki persentase tanaman hidup, rata - rata diameter dan rata - rata tinggi yang baik yaitu Hasminar $(38,3 \%)$, hal ini dikarenakan melakukan pemeliharaan pada tahun pertama terhadap tanaman gaharu yang ditanam diantaranya pemberian pupuk npk dan urea, dan penyiangan sebanyak 1 (satu) kali dalam satu tahun. Sedangkan anggota kelompok tani yang tidak melakukan pemeliharaan memiliki persentasi tanaman hidup yang drendah diantaranya Wati, Arizal dan Rizal dengan persentase tanaman yang hidup 20 $\%$.

Beberapa faktor yang mempengaruhi rendahnya persentase keberhasilan tanaman gaharu pada kelompok tani halaman kuyang lestari diantaranya yaitu tidak adanya naungan pada saat penanaman tanaman gaharu, banjir yang terjadi pada Tahun 2017 sehingga menyebabkan banyak tanaman gaharu yang mati terkena banjir, adanya hama babi dan hama monyet yang menjadi kendala dalam pertumbuhan tanaman karet di lahan Kelompok Tani Halam Kuyang Lestari ini. Selain faktor tersebut diatas, kurangnya pendampingan tentang budidaya gaharu yang baik sehingga masyarakat tidak melakukan kegiatan penanaman gaharu sesuai cara penanaman gaharu yang baik.

\section{d. Analisis Ekonomi Budidaya Lebah Madu}

\section{Biaya Produksi}

Untuk menghitung biaya produksi, dapat dihitung dengan total biaya dalam budidaya lebah madu, Soekartawi (2002) menyatakan bahwa biaya merupakan penjumlahan antara biaya tetap dan biaya variabel yang dikeluarkan selama satu tahun. Dalam usaha budidaya lebah madu, 
yang termasuk dalam biaya tetap adalah biaya penyusutan stup dan penyusutan alatalat. Hasil penelitian menunjukkan bahwa rata-rata biaya tetap yang dikeluarkan oleh Kelompok Tani Halaman Kuyang Lestari per tahun Rp. 6.375.000,-. Rincian rata-rata jumlah biaya penyusutan stup dan alat-alat dapat dilihat pada tabel 6:

Tabel 6. Biaya Penyusutan Stup dan Alat-alat pada Budidaya Lebah Madu Kelompok Tani Halaman Kuyang Lestari per Tahun

\begin{tabular}{|c|c|c|c|}
\hline No & Komponen Biaya Tetap & $\begin{array}{c}\text { Biaya Rata - Rata } \\
\text { (Rp/ Tahun) }\end{array}$ & $\begin{array}{c}\text { Persentase } \\
(\%)\end{array}$ \\
\hline 1 & Penyusutan Stup & 3.375 .000 & 40,00 \\
\hline 2 & $\begin{array}{l}\text { Penyusutan Perbaikan } \\
\text { Toping }\end{array}$ & 2.550 .000 & 52,94 \\
\hline 3 & Penyusutan Mesin Panen & 450.000 & 7,06 \\
\hline & Jumlah & 6.375 .000 & 100,00 \\
\hline
\end{tabular}

Rincian rata - rata jumlah biaya variabel dapat dilihat pada tabel 7 :

Tabel 7. Rata - Rata Jumlah Biaya Variabel pada Budidaya Lebah Madu Kelompok Tani Halaman Kuyang Lestari per Tahun

\begin{tabular}{rlrr}
\hline No & \multicolumn{1}{c}{$\begin{array}{c}\text { Komponen Biaya } \\
\text { Variabel }\end{array}$} & $\begin{array}{c}\text { Biaya Rata - Rata } \\
\text { (Rp/ Tahun) }\end{array}$ & $\begin{array}{c}\text { Persentase } \\
(\%)\end{array}$ \\
\hline 1 & $\begin{array}{l}\text { Operasional Minyak } \\
\text { (Transportasi) }\end{array}$ & 2.400 .000 & 17,65 \\
\hline 2 & Biaya Pengemasan & 1.200 .000 & 8,82 \\
\hline 3 & Biaya Tenaga Kerja & 9.000 .000 & 66,18 \\
\hline 4 & Baju Lebah & 1.000 .000 & 7,35 \\
\hline & & 13.600 .000 & 100,00 \\
\hline
\end{tabular}

Diketahui biaya produksi dalam 1 (satu) tahun dalam budidaya lebah madu ini yaitu Rp.19.975.000,-.

\section{Penerimaan}

Rata - rata produksi madu per bulan yaitu 9 liter dari 30 stup yang dimiliki. Harga jual madu di Desa Rumbio saat ini yaitu Rp.450.000 per 1 liter. Sehingga diketahui penerimaan per bulan dari budidaya lebah madu ini yaitu sebesar Rp.4.050.000,-. Sehingga dalam satu tahun bisa mendapatkan penerimaan sebesar Rp.48.600.000,-.

\section{Keuntungan}

Rata-rata pendapatan bersih/ keuntungan yang diterima oleh 7 orang anggota Kelompok Tani Halaman Kuyang Lestari ini Rp.28.625.000 pertahun. Rata rata pendapatan/ keuntungan yang diterima relatif tinggi bila dibandingkan dengan besarnya rata-rata biaya produksi yang dikeluarkannya. Hal ini disebabkan oleh harga jual madu yang tinggi, sementara biaya produksi yang dikeluarkan relatif rendah.

\section{Analisis Kelayakan Usaha}

Dari perhitungan Nilai Break Even Point diatas, diketahui bahwa Nilai NBEP pada budidaya lebah madu ini yaitu 22 liter/ tahun. Dengan demikian usaha ini dianggap layak karena menghasilkan NPV yang positif. Menguntungkan atau tidaknya 
usaha budidaya lebah madu yang dilakukan secara ekonomi dapat dianalisis sebagai berikut:

$$
\begin{aligned}
\boldsymbol{R C} \boldsymbol{R}= & \mathbf{P T} / \mathbf{B T} \\
& =48.600000 / 19.975 .000 \\
& =2,43
\end{aligned}
$$

Soekartawi (1995) menyatakan bahwa jika R/C > 1, maka usahatani yang dilakukan menguntungkan karena penerimaan lebih besar dari biaya total. Dari perhitungan diatas, diketahui bahwa nilai RCR budidaya lebah madu ini 2 maka usaha budidaya lebah madu yang dilakukan secara ekonomi menguntungkan.

\section{e. Tindakan Silvikultur}

Areal lahan Kelompok Tani Halaman Kuyang Lesatri untuk penyiapan lahan dilakukan dengan membuat jalur tanam. Teknik pembersihan lahan yang dilakukan yaitu penebangan atau pemotongan semua semak- semak, tanaman perambat, dan anak kayu diameter $<10 \mathrm{~cm}$ dipotong $<20 \mathrm{~cm}$ dari tanah. Teknik tersebut disebut Imas, dengan tenaga kerja yang digunakan sekitar 1 s.d. 6 orang. Adapun alat yang digunakan dalam pembersihan lahan ini yaitu parang dan kapak.

Bibit yang digunakan dalam penanaman pada lahan Kelompok Tani
Halaman Kuyang Lestari merupakan bantuan bibit Kebun Bibit Rakyat (KBR) yang berasal dari Pemerintah Balai Pengelolaan Daerah Alirasn Sungai (BPDAS) Indragiri Rokan. Bentuk bantuan bibit KBR ini merupakan hasil pembibitan yang dilakukan oleh Kelompok Tani Halaman Kuyang Lestari.

Untuk tanaman karet, bibit yang digunakan dalam persemaian berasal dari biji/benih. Perlakuan untuk benih ini dimulai dari biji yang disemaikan dalam bedeng tabur sampai berkecambah dan muncul minimal 2 daun. Kemudian disapih dalam wadah, dan ditempatkan pada bedeng sapih. Setelah bibit berumur 3-4 bulan atau batang telah berkayu, bibit siap ditanam di lapangan (P.04/VI-BUHT/2012). Sedangkan untuk tanaman gaharu bibit merupakan bibit cabutan berasal dari daerah Lampung yang berupa anakan yang dicabut dan dipindahkan ke wadah. Adapun jumlah bibit yang diperoleh Kelompok Tani Halaman Kuyang Lestari yaitu 15.000 bibit untuk tanaman karet dan 10.000 bibit untuk tanaman gaharu.

Untuk tanaman karet, jarak tanam yang digunakan oleh Kelompok Tani Halaman Kuyang Lestari beragam, diantaranya yaitu 
$2,5 \times 3 \mathrm{~m} ; 4 \times 5 \mathrm{~m}$; dan $6 \times 6 \mathrm{~m}$ dengan kedalaman lubang tanam $30 \mathrm{~cm}$. Beberapa anggota Kelompok Tani Halaman Kuyang Lestari menggunakan pupuk dasar NPK dimana pupuk ini merupakan pupuk yang dibeli pribadi oleh anggota Kelompok Tani yang menggunakan pupuk.

Sedangkan untuk tanaman gaharu, bibit ditanam disela - sela pohon karet dengan jarak tanam yang digunakan diantaranya $4 \mathrm{x}$ $4 \mathrm{~m} ; 5 \times 3 \mathrm{~m}$; dan 6 × $5 \mathrm{~m}$ dengan kedalaman lubang tanam $30 \mathrm{~cm}$. Beberapa anggota kelompok tani juga menggunakan pupuk NPK sebagai pupuk dasar pada awal penanaman dengan dosis pupuk yang digunakan yaitu 1 sdk per tanaman.

Pemeliharaan untuk tanaman karet dan tanaman gaharu antara lain melalui kegiatan penyulaman, penyiangan, pemupukan hingga pengendalian hama dan penyakit. Pada usia tanaman 1 hingga 4 tahun, beberapa anggota kelompok tani melakukan pemeliharaan terhadap tanaman karet yang ditanam. Namun untuk tanaman gaharu, anggota Kelompok Tani Halaman Kuyang Lestari relatif sedikit yang melakukan pemeliharaan.

Kegiatan penyulaman pada tanaman karet dilakukan pada tahun pertama setelah penanaman, namun untuk tanaman gaharu penyulaman tidak pernah dilakukan dikarenakan tidak tersedianya bibit gaharu untuk penyulaman. Untuk penyiangan tanaman karet hanya sebagian anggota Kelompok Tani Halaman Kuyang Lestari yang melakukan penyiangan, sedangkan untuk penyiangan tanaman gaharu dilakukan hanya oleh 3 (tiga) orang anggota kelompok tani. Dikarenakan tidak tersedianya bantuan pupuk, maka hanya 7 (tujuh) orang anggota Kelompok Tani Halaman Kuyang Lestari yang memberikan pupuk terhadap tanaman karet yang sudah ditanam dan 1 (satu) orang untuk tanaman gaharu.

\section{KESIMPULAN DAN SARAN}

\section{A. Kesimpulan}

Pertumbuhan tanaman karet yang berumur 4 tahun memiliki diameter rata rata $29,09 \mathrm{~cm}$ dan tinggi total rata - rata 5,75 m sedangkan tanaman gaharu yang berumur 4 tahun memiliki diameter rata rata $16,28 \mathrm{~cm}$ dan tinggi bebas cabang rata - rata 2,42 m. Keberhasilan tanaman yang hidup untuk tanaman karet $53 \%$ dan untuk tanaman gaharu $28 \%$. 
Tindakan silvikultur pada tanaman karet dan tanaman gaharu mempengaruhi pertumbuhan diameter dan tinggi tanaman. Tindakan silvikultur yang dilaksanakan oleh anggota Kelompok Tani Halaman Kuyang Lestari terbatas pada kegiatan pemupukan dan penyiangan tanaman.

Budidaya lebah madu yang dilakukan oleh 7 (tujuh) orang Kelompok Tani Halaman Kuyang Lestari secara ekonomi menguntungkan yaitu \pm Rp.28.625.000,- per tahun.

\section{B. Saran}

Dari penelitian ini disarankan agar Kelompok Tani Halaman Kuyang Lestari mengusulkan untuk mendapatkan pendampingan kepada pemerintah terhadap program ke depannya dalam rangka pengembangan tanaman yang ada di Desa Rumbio, terutama dalam hal memanfaatkan lahan yang kosong.

\section{DAFTAR PUSTAKA}

Amir. (2011). Evaluasi Kinerja Kelompok Pengelola Kebun Bibit Rakyat (Kbr) di Kabupaten Biak Numfor. Universitas Negeri Papua Manokwari.

Hairiah K, Agung M, S. S. (2003). Pengantar Agroforestry. Bogor: World Agroforestry Centre (ICRAF)
Southeast Asia.

Hasanu, S. (2017). Metode Inventore Hutan. Yogyakarta: Pustaka Pelajar.

Muin, A. (2018). Pertumbuhan Tanaman Gaharu (Aquilaria Malaccensis Lamk) Pada Tanah Aluvial Dengan Naungan Dan Tinggi Bibit Berbeda (Growth Of Agarwood (Aquilaria Malaccensis Lamk ) Plants On Alluvial Soil With Different Shades And High Of Seedlings). In Hutan Lestari (Vol. 6).

Riyanto, B. (2008). Dasar - Dasar Pembelanjaan Perusahaan. Yogyakarta: Yayasan Badan Penerbit Gadjah Mada.

Soekartawi. (1995). Prinsip Dasar Ekonomi Pertanian. Jakarta: PT.Raja Grafindo Persada.

Soekartawi. (2002). Analisis Usahatani. In Universitas Indonesia Press.

Soekartawi. (2006). Agribisnis Teori dan Aplikasi. Jakarta: Rajawali Press.

Sulistiono, N., Insusanty, E., \& Azwin, A. (2018). Survei Potensi Gaharu Dengan Sistem Agroforestri di Kecamatan Xiii Koto Kampar, Kabupaten Kampar (Studi Kasus: Desa Pulau Gadang dan Desa Koto Masjid). Wahana Forestra: Jurnal

Kehutanan. https://doi.org/10.31849/forestra.v13i1 .1280 